\title{
EFISIENSI EKONOMI PENGGUNAAN FAKTOR-FAKTOR PRODUKSI, PENDAPATAN USAHATANI JAGUNG HIBRIDA DAN JAGUNG LOKAL DI KECAMATAN KEMUSU, KABUPATEN BOYOLALI
}

\section{(Economic Efficiency Of Production Factors Allocation, Income Of Hybrid Maize Farming and Local Maize in Kemusu Sub-District, Boyolali Regency)}

\author{
A. Wahyuningsih ${ }^{1)}$, B.M. Setiawan ${ }^{2)}$, dan B.A. Kristanto ${ }^{2)}$ \\ 1) Mahasiswa Program Magister Agribisnis Universitas Diponegoro, \\ Badan Ketahanan Pangan Kementerian Pertanian RI \\ 2) Dosen Fakultas Peternakan dan Pertanian Universitas Diponegoro \\ Email: ari.wahyu82@gmail.com
}

Diterima 21 Juli 2017, disetujui 14 November 2017

\begin{abstract}
ABSTRAK
Penelitian ini bertujuan untuk (i) menganalisis faktor produksi yang berpengaruh terhadap produksi jagung (ii) menganalisis efisiensi ekonomi penggunaan faktor produksi usahatani jagung, dan (iii) menganalisis pendapatan usahatani jagung. Penelitian dilakukan di Kecamatan Kemusu Kabupaten Boyolali dengan metode survei dan jumlah responden sebanyak 175 petani jagung. Hasil analisis dengan fungsi produksi model Cobb-Douglas menunjukkan bahwa variabel jumlah benih, pupuk NPK, tenaga kerja, usia petani, pengalaman petani bertani jagung, dan dummy varietas jagung hibrida berpengaruh nyata terhadap produksi jagung hibrida. Produksi jagung lokal secara nyata dipengaruhi oleh faktor produksi benih, pupuk kandang, pupuk NPK, dan tenaga kerja. Secara ekonomi penggunaan variabel benih, pupuk kandang, pupuk NPK dan pupuk SP36 pada usahatani jagung hibrida belum efisien, dan penggunaan variabel pupuk Urea, pestisida dan tenaga kerja tidak efisien. Penggunaan variabel benih, pupuk kandang, dan pupuk NPK pada usahatani jagung lokal belum efisien, penggunaan pupuk urea, pestisida dan tenaga kerja tidak efisien. Usahatani jagung di Kecamatan Kemusu Kabupaten Boyolali menguntungkan, hasil uji beda menunjukkan adanya perbedaan yang nyata antara pendapatan usahatani jagung hibrida dan jagung lokal.
\end{abstract}

Kata kunci: efisiensi, pendapatan, usahatani jagung.

\section{ABSTRACT}

The objectives of this research were (i) analyzing factors influencing of maize production, (ii) analyzing the economic efficiency of production factors allocation for maize farms, and (iii) analyzing the income of maize farms. The research was conducted in Kemusu sub-district, Boyolali Regency using survey method. The number of respondents was 175 maize farmers. The result of analysis with Cobb-Douglas model production function showed that seed variables, NPK fertilizer, labor, farmer age, farmer experience of maize, and dummy hybrid maize varieties had significant effect on hybrid maize production. Local maize production was significantly influenced by factors of seed production, manure, NPK fertilizer, and labor. Economically the use of seed variables, manure, NPK fertilizer and SP36 fertilizer on hybrid 
maize farming was inefficient, and the use of urea fertilizer, pesticide, and labor was inefficient. The use of seed variables, manure, and NPK fertilizer has not been efficient, the use of variable urea fertilizers, pesticides and labor on local maize farming was inefficient. Maize farming in Kemusu sub-district, Boyolali regency is profitable and still feasible to cultivate. Different test results of independent sample t-test showed a significant difference between the income of hybrid maize and local maize.

Keywords: efficiency, income, maize farming

\section{PENDAHULUAN}

Jagung di Indonesia merupakan salah satu komoditas pangan utama setelah padi, jagung termasuk komoditas strategis dalam pembangunan pertanian dan penggerak roda perekonomian Nasional. Rata-rata poduksi jagung nasional mengalami kenaikan sebesar 6,31 persen selama periode 2006 - 2015 (Badan Pusat Statistik, 2016), namun pada kenyataannya sampai tahun 2015, Indonesia belum mampu memenuhi permintaan jagung dalam negeri, terutama untuk industri pakan. Impor jagung tahun 2015 sebesar 3,267 juta ton (Pusat Data dan Informasi Kementerian Pertanian, 2016). Permintaan jagung dalam negeri cenderung meningkat dengan rata-rata pertumbuhan selama periode 2006 - 2015 sebesar 6,40 persen (Badan Ketahanan Pangan, 2016). Permintaan jagung di pasar domestik maupun pasar dunia semakin meningkat seiring dengan berkembangnya industri pakan dan industri pangan olahan berbahan baku jagung.

Usaha untuk meningkatkan produksi jagung Indonesia telah banyak dilakukan akan tetapi hasilnya masih belum memuaskan, salah satu program pemerintah tersebut yaitu Gerakan Pengembangan Jagung Hibrida 2016 yang bertujuan untuk peningkatan produksi jagung. Pada tahun 2016 Kabupaten Boyolali merupakan salah satu kabupaten yang masuk dalam program tersebut. Wilayah kecamatan di Kabupaten Boyolali semua terdapat tanaman jagung. Jagung yang ditanam oleh petani menggunakan varietas hibrida sebanyak 60 persen, varietas unggul lokal dan komposit, masing-masing 25 dan 15 persen. Kecamatan Kemusu merupakan kecamatan sentra produksi jagung di Kabupaten Boyolali, pada tahun 2015 telah memasok jagung sebanyak 17,80 persen dari total produksi di Kabupaten Boyolali Tahun 2015 (Badan Pusat Statistik Kabupaten Boyolali, 2016). Rata-rata produktivitas jagung sebesar 41,59 ku/ha atau hampir sama dengan ratarata produktivitas jagung Kabupaten Boyolali 41,35 ku/ha atau dibawah produktivitas jagung di Jawa Tengah 59,18 ku/ha.

Rendahnya produktivitas jagung tersebut diduga disebabkan oleh beberapa faktor antara lain petani masih belum efisien dalam mengalokasikan input-input produksi yang digunakan dalam usahataninya, serta pengelolaan usahatani dan teknologi yang masih sederhana sehingga menghasilkan produksi yang kurang maksimal dan pada akhirnya berpengaruh pada pendapatan petani. Soekartawi (2016) menyatakan bahwa pilihan terhadap kombinasi penggunaan tenaga kerja, benih, pupuk, obat-obatan yang optimal akan mendapatkan hasil yang maksimal. Menurut (Saptana, 2011), tingkat pengalokasian penggunaan faktor produksi oleh petani tersebut berpengaruh terhadap jumlah produksi yang dihasilkan, tingkat produktivitas, dan dapat memberikan gambaran mengenai tingkat efisiensi yang dicapai petani.

Tujuan dari penelitian ini yaitu: (1) menganalisis faktor-faktor produksi yang mempengaruhi produksi jagung hibrida dan jagung lokal di Kecamatan Kemusu Kabupaten Boyolali; (2) menganalisis efisiensi ekonomi penggunaan faktor-faktor produksi usahatani jagung hibrida dan jagung lokal di Kecamatan Kemusu, Kabupaten Boyolali dan (3) menganalisis pendapatan usahatani jagung hibrida dan jagung lokal di Kecamatan Kemusu Kabupaten Boyolali.

\section{METODE PENELITIAN}

\section{Metode Penelitian dan Jenis Data}


Penelitian ini dilaksanakan di Kecamatan Kemusu, Kabupaten Boyolali Provinsi Jawa Tengah pada bulan April sampai dengan Juli 2017, dengan metode survei. Penentuan sampel secara multi stage sampling, diperoleh 100 petani jagung hibrida dan 75 petani jagung lokal. Penelitian ini menggunakan data primer dan sekunder. Data primer diperoleh dari petani responden dengan menggunakan kuesioner. Data yang dikumpulkan meliputi: identitas petani, penggunaan modal, usahatani jagung musim tanam periode September 2016 - Januari 2017 (penggunaan benih, pupuk, pestisida, tenaga kerja, dan pengeluaran lain dari usahatani jagung), produksi dan penanganan pasca panen, manajemen dan pemasaran. Data sekunder diperoleh dari Kementerian Pertanian RI, Dinas Pertanian, Perkebunan dan Kehutanan Kabupaten Boyolali, dan Badan Pusat Statistik. Data tersebut meliputi: data produksi, luas panen, produktivitas, permintaan jagung dalam negeri, impor jagung, dan data petani jagung, serta data pendukung lainnya yang terkait dalam penelitian.

\section{Metode Analisis Data}

Metode analisis data digunakan analisis deskriptif dan analisis inferensial guna menjawab tujuan penelitian. Data yang sudah ditabulasi selanjutnya dilakukan uji asumsi model fungsi produksi Cobb-Douglas, yang hasilnya berupa persamaan regresi.

Analisis untuk tujuan pertama yaitu analisis pengaruh faktor-faktor produksi (input) terhadap hasil produksi (output) menggunakan model fungsi produksi CobbDouglas yang ditransformasikan dalam bentuk In (logaritma natural) (Soekartawi 2002), sehingga persamaannya sebagai berikut:

a) Model persamaan fungsi produksi untuk usahatani jagung hibrida dengan dummy varietas:

$\operatorname{LnY}=\operatorname{Ln} a_{0}+b_{1} \operatorname{LnX} 1+b_{2} \operatorname{LnX} 2-b_{3}$
$\operatorname{LnX} 3+b_{4} \operatorname{LnX} 4+b_{5} \operatorname{LnX} 5-b_{6} \operatorname{LnX} 6-$
$b_{7} \operatorname{LnX} 7+b_{8} \operatorname{LnX} 8-b_{9} \operatorname{LnX} 9+b_{10}$
$\mathrm{LnX} 10+\mathrm{b}_{{ }_{11}} \mathrm{D}+\mathrm{U}$

Variabel Y yaitu produksi jagung hibrida (kg), X1 jumlah benih (kg), X2 jumlah pupuk $(\mathrm{kg})$ kandang, X3 jumlah pupuk urea $(\mathrm{kg}), \mathrm{X} 4$ jumlah pupuk majemuk Nitrogen Fosfor dan Kalium (NPK Phonska) (kg), X5 jumlah pupuk SP 36 (kg), X6 jumlah pestisida (liter)), X7 jumlah tenaga kerja (HKSP), X8 usia petani (tahun), X9 pengalaman petani bertani jagung (kali), X10 frekuensi petani dalam mengikuti penyuluhan jagung (kali), dan D merupakan dummy varietas hibrida.

b) Model persamaan fungsi produksi untuk usahatani jagung lokal:

$\operatorname{LnY}=\operatorname{Ln} a_{0}+b_{1} \operatorname{LnX} 1+b_{2} \operatorname{LnX} 2-b_{3}$ $\operatorname{LnX} 3+b_{4} \operatorname{LnX} 4+b_{5} \operatorname{LnX} 5-b_{6} \operatorname{LnX} 6-$ $b_{7} \operatorname{LnX} 7+b_{8} \operatorname{LnX} 8-b_{9} \operatorname{LnX} 9$

$+\mathrm{U}$

Variabel Y yaitu produksi jagung lokal (kg) , X1 jumlah benih (kg), X2 jumlah pupuk kandang $(\mathrm{kg}), \mathrm{X} 3$ jumlah pupuk urea (kg), X4 jumlah pupuk NPK (kg), X5 jumlah pestisida (liter), X6 jumlah tenaga kerja (HKSP), X7 usia petani (tahun ), X8 pengalaman petani bertani jagung (kali), dan X9 frekuensi petani dalam mengikuti penyuluhan jagung (kali).

Pengaruh variable independent terhadap hasil produksi pada model diatas diuji menggunakan uji F dan uji t (Ghozali, 2011).

Analisis tujuan yang kedua yaitu efisiensi ekonomi yang merupakan salah satu cara untuk mengukur tingkat keberhasilan petani dalam usahanya untuk mencapai keuntungan maksimum. Nilai efisiensi ekonomi dihitung dengan mencari rasio nilai produk marginal dari masing-masing faktor produksi $\left(\mathrm{NPM}_{\mathrm{xi}}\right)$ sama dengan harga input nya $\left(\mathrm{P}_{\mathrm{xi}}\right)$ (Shinta, 2011).

$$
\begin{aligned}
& \quad N P M_{x 1}=\bar{P}_{x 1} \\
& \beta_{x 1} \cdot \overline{\bar{Y}} \cdot \bar{P}_{y}=\overline{P_{x 1}} \\
& \quad \mathrm{NPM}_{\mathrm{xi}} \text { merupakan nilai produk marjinal } \\
& \text { faktor produksi ke-i, } \mathrm{P}_{\mathrm{xi}}=\text { rata-rata harga }
\end{aligned}
$$


input faktor produksi ke-i, $\beta_{\mathrm{xi}}=$ koefisien regresi faktor produksi ke-i, $\bar{y}=$ output (produksi) rata-rata, $\bar{X}_{i}=$ input rata-rata, dan $\quad \bar{p}_{y}=$ harga output (jual) rata-rata.

Secara ekonomi, jika $\frac{N P M_{x i}}{P x i}=1$

berarti penggunaan faktor produksi optimum atau efisien, $\frac{N P M_{x i}}{P x i}>1$ berarti penggunaan faktor produksi belum optimum atau belum efisien sehingga input perlu ditambah, dan $\frac{N P M_{x i}}{P x i}<1$ berarti penggunaan faktor produksi tidak optimum atau tidak efisien, sehingga input perlu dikurangi (Soekartawi, 2002).

Analisis tujuan yang ketiga yaitu analisis pendapatan. Usahatani jagung adalah kegiatan untuk memproduksi yang pada akhirnya akan dinilai dari biaya yang dikeluarkan dan penerimaan atau pendapatan yang diperoleh. Salah satu ukuran efisiensi pendapatan adalah penerimaan (R) untuk setiap biaya (C) yang dikeluarkan (Suratiyah, 2015). Penerimaan atau pendapatan kotor adalah seluruh pendapatan yang diperoleh dari usahatani selama satu periode diperhitungkan dari hasil penjualan atau penaksiran kembali. Secara matematis dapat dirumuskan yaitu $\Pi=\mathrm{TR}-$ TC, $\pi$ merupakan pendapatan, TR (Total Revenue $=$ jumlah produksi dikalikan dengan harga satuan, dan TC (Total Cost $)=$ Biaya total yaitu penjumlahan dari biaya tetap (FC) dan biaya variabel (VC).

Analisis $\mathrm{R} / \mathrm{C}$ ratio pada usahatani menunjukkan perbandingan antara penerimaan yang diterima untuk setiap rupiah yang dikeluarkan untuk memproduksi. Semakin besar nilai $\mathrm{R} / \mathrm{C}$ ratio menunjukkan semakin besar juga penerimaan usahatani yang diperoleh untuk setiap rupiah biaya yang dikeluarkan (Suratiyah, 2015). Besaran parameter yang diharapkan jika nilai $\mathrm{R} / \mathrm{C}$ ratio menunjukkan angka lebih dari satu yang berarti usahatani layak.

\section{HASIL DAN PEMBAHASAN}

\section{Karakteristik dan Penggunaan Input Usahatani}

Kepemilikan lahan jagung hibrida sebanyak 17 persen lahan milik sendiri dan 83 persen lahan sewa, sedangkan kepemilikan lahan jagung lokal sebanyak 41 persen lahan milik sendiri dan 59 persen lahan sewa. Luas lahan yang diusahakan petani responden beragam yaitu rata-rata luas lahan jagung hibrida sebesar 0,40 hektar atau lebih luas jika dibandingkan rata-rata luas lahan jagung lokal yang diusahakan petani sebesar 0,27 hektar. Benih jagung yang digunakan petani ada dua jenis yaitu benih hibrida dan benih lokal. Benih hibrida meliputi varietas Bisi-18 dan Pioner-21 yang pada umumnya benih jagung hibrida diperoleh petani dengan cara membeli di toko sarana produksi pertanian (saprotan), dan untuk benih jagung lokal yaitu jagung unyil yang diperoleh sebagian petani dengan cara membuat benih sendiri dari hasil panennya dan sebagian diperoleh dari toko Saprotan. Rata-rata jumlah benih jagung yang digunakan petani jagung hibrida sebesar $15,14 \mathrm{~kg} / \mathrm{ha}$ dan petani jagung lokal sebesar $16,83 \mathrm{~kg} / \mathrm{ha}$. Seratus persen petani melakukan pemupukan dengan pupuk kandang dan buatan. Rata-rata penggunaan pupuk kandang oleh petani hibrida sebesar $811,99 \mathrm{~kg} / \mathrm{ha}$ dan jagung lokal yaitu $868,89 \mathrm{~kg} / \mathrm{ha}$. Pupuk buatan yang digunakan petani hibrida meliputi pupuk urea, pupuk NPK Phonska, dan pupuk SP 36, dengan rata-rata jumlah pupuk secara berurutan $323,39 \mathrm{~kg} / \mathrm{ha}, 284,53$ $\mathrm{kg} / \mathrm{ha}$, dan $76,68 \mathrm{~kg} / \mathrm{ha}$. Rata-rata penggunaan pupuk oleh petani jagung lokal yaitu pupuk urea $305,89 \mathrm{~kg} / \mathrm{ha}$, dan pupuk NPK 284,22 $\mathrm{kg} / \mathrm{ha}$. Semua petani Jagung lokal tidak menggunakan pupuk SP 36, dengan alasan keterbatasan modal dan waktu tanam yang lebih pendek yaitu hanya sekitar 70-75 hari. Penggunaan pupuk SP 36 oleh petani jagung hibrida dilakukan oleh petani karena kondisi warna daun yang tidak seragam atau warna daun kurang hijau yang akan menghambat pembentukan bunga serta masaknya daun.

Pestisida yang digunakan berupa herbisida seperti merk: Round Up, See Top, Lindomin, DMA, Kayabas, dan Calaris, yaitu 
digunakan untuk membasmi gulma pada tahap awal penyiapan lahan dan tahap pemeliharaan tanaman yaitu penyiangan. Rata-rata jumlah herbisida yang digunakan oleh petani hibrida sebesar 8,72 liter/ha dan jagung lokal sebesar 11,21 liter/ha. Tenaga kerja terdiri dari tenaga kerja keluarga dan tenaga kerja tambahan dari luar keluarga. Tenaga kerja tambahan dari luar biasanya diperlukan pada saat olah tanam, penanaman benih, dan pasca panen. Upah tenaga kerja bervariasi, akan tetapi pada penelitian ini upah kerja menggunakan satuan HKSP atau harian kerja setara pria yaitu berkisar $\mathrm{Rp}$ 70.000 - Rp 80.000 per hari. Rata-rata jumlah tenaga kerja yang digunakan usahatani jagung hibrida sebesar 72,93 HKSP/ha dan jagung lokal sebesar 89,26 HKSP/ha. Rata-rata usia petani responden antara petani jagung hibrida dan petani jagung lokal yaitu masing-masing berusia 53 dan 52 tahun. Rata-rata pengalaman berusahatani jagung oleh petani jagung hibrida 45 kali bertanam jagung dan petani jagung lokal yaitu 47 kali bertanam jagung. Pengalaman berusahatani jagung oleh petani dihitung dari berapa kali petani responden sudah melaksanakan budidaya jagung selama hidupnya atau dari pertama kali budidaya jagung sampai Desember 2016. Rata-rata frekuensi keikutsertaan petani dalam penyuluhan oleh petani jagung hibrida sebanyak 3 kali dan petani jagung lokal sebanyak 4 kali. Keikutsertaan petani pada kegiatan penyuluhan dengan materi komoditas jagung dalam penelitian ini dihitung selama dua tahun terakhir yaitu dari periode Januari 2015 - Desember 2016.

\section{Faktor-Faktor Yang Berpengaruh Terhadap Produksi Jagung}

Fungsi produksi model Cobb-Douglas digunakan dalam rangka untuk pembuktian hipotesis penelitian, karena hasil pengujian variabel data yang digunakan telah memenuhi syarat uji asumsi klasik. Berdasarkan hasil uji asumsi klasik, data masing-masing variabel terdistribusi normal yaitu nilai KolmogorovSmirnov (KS) jagung hibrida sebesar 0,983 dan signifikansi pada 0,288 (sig. $>0,05)$ dan nilai Kolmogorov-Smirnov (KS) usahatani jagung lokal sebesar 0,537 dan signifikan pada $0,935 \quad$ (sig. $>0,05)$. Tidak terjadi multikolinieritas antara variabel independen pada usahatani jagung hibrida dan jagung lokal yaitu nilai tolerance $>0,10$ dan nilai $\mathrm{VIF}<10$. Hasil pengamatan grafik Scatterplot dari kedua usahatani jagung tidak terdapat heteroskedastisitas dan dari uji run test tidak terjadi autokorelasi antara residual. Hasil uji $\mathrm{R}^{2}$ menunjukkan bahwa variabel-variabel yang digunakan pada usahatani jagung hibrida tersebut diatas memiliki proporsi sumbangan terhadap produksi jagung hibrida sebesar 84,8 persen, dan 15,2 persen dijelaskan oleh variabel lain diluar model. Variabel-variabel yang digunakan pada usahatani jagung lokal tersebut diatas memiliki proporsi sumbangan terhadap produksi jagung lokal sebesar 86,5 persen dan 13,5 persen dijelaskan oleh variabel lain diluar model. Hasil uji F menunjukkan bahwa nilai signifikan usahatani jagung hibrida dan jagung lokal sebesar 0,000 atau lebih kecil dari 0,05 yang artinya paling sedikit salah satu faktor produksi benih, pupuk kandang, pupuk urea, pupuk NPK, pupuk SP36, pestisida, tenaga kerja, usia, pengalaman petani bertani jagung, frekuensi keikutsertaan petani dalam kegiatan penyuluhan jagung, dan varietas hibrida secara bersama-sama berpengaruh nyata terhadap produksi jagung hibrida. Hasil uji $\mathrm{F}$ pada usahatani jagung lokal menunjukkan bahwa paling sedikit salah satu faktor produksi benih, pupuk kandang, pupuk urea, pupuk NPK, tenaga kerja, usia, pengalaman petani bertani jagung, dan frekuensi keikutsertaan petani dalam kegiatan penyuluhan jagung secara bersama-sama berpengaruh nyata terhadap produksi jagung lokal.

Tabel 1, menunjukkan bahwa faktor produksi benih, pupuk NPK, tenaga kerja, usia petani, pengalaman petani bertani jagung, dan dummy varietas jagung berpengaruh terhadap produksi jagung hibrida $(\alpha=0,05)$. Variabel yang berpengaruh nyata pada produksi jagung lokal yaitu benih, pupuk kandang, pupuk NPK, dan tenaga kerja 
pada tingkat $\alpha=0,05$.

Variabel benih berpengaruh nyata pada usahatani jagung hibrida dan jagung lokal, dengan nilai koefisien regresi positif. Hasil tersebut sesuai dengan penelitian Fadwiwati dan Tahir (2013), Isaac (2011), dan Nursan (2015) yang menyatakan bahwa jumlah benih berpengaruh positif dan nyata terhadap produksi jagung. Variabel pupuk kandang nilai koefisien regresi pada usahatani jagung hibrida dan lokal bernilai positif, Pemberian pupuk organik pada penelitian ini yaitu berupa pupuk kandang akan menambah unsur hara yang dibutuhkan dalam pertumbuhan tanaman. Menurut Ayub dan Pranata (2010), serta Meade et al., 2011 menyatakan bahwa penambahan pupuk kandang pada awal penanaman jagung dapat berpengaruh positif pada produksi jagung. Variabel jumlah pupuk NPK memiliki pengaruh positif pada usahatani jagung hibrida dan jagung lokal. Menurut hasil penelitian Pratikta et al. (2013), bahwa penambahan pupuk NPK dengan dosis $300 \mathrm{~kg} / \mathrm{ha}$ cenderung memberikan hasil yang baik pada empat varietas tanaman jagung yang dicobakan. Hasil ini sama dengan hasil penelitian Kasno dan Rostaman (2013), bahwa pemberian pupuk NPK 15-15-15 berpengaruh nyata meningkatkan bobot pipilan kering biji jagung.

Variabel tenaga kerja pada kedua usahatani jagung hibrida dan lokal

Tabel 1. Hasil Analisis Pengaruh Faktor Produksi yang Digunakan Terhadap Produksi Jagung Hibrida dan Lokal

\begin{tabular}{|c|c|c|c|c|c|c|c|c|}
\hline \multirow[t]{2}{*}{ Faktor Produksi } & & \multicolumn{2}{|c|}{ Jagung Hibrida } & & \multicolumn{4}{|c|}{ Jagung Lokal } \\
\hline & & $\begin{array}{l}\text { Koefisien } \\
\text { Regresi }\end{array}$ & Sig. & & & $\begin{array}{c}\text { Koefisien } \\
\text { Regresi }\end{array}$ & Sig. & \\
\hline Konstanta & & 2.449 & .016 & & & 1.823 & 0.22 & \\
\hline Benih & $\mathrm{X} 1$ & .975 & .000 & $* *$ & $\mathrm{X} 1$ & .551 & .000 & $* *$ \\
\hline Pupuk kandang & $\mathrm{X} 2$ & .109 & .171 & ns & $\mathrm{X} 2$ & .141 & .031 & $*$ \\
\hline Pupuk Urea & X3 & -.094 & .300 & ns & $\mathrm{X} 3$ & -.106 & .373 & ns \\
\hline Pupuk NPK & $\mathrm{X} 4$ & .290 & .007 & $* *$ & $\mathrm{X} 4$ & .302 & .000 & $* *$ \\
\hline Pupuk SP36 & X5 & .030 & .081 & ns & & & & \\
\hline Pestisida & X6 & -.008 & .840 & ns & $\mathrm{X} 5$ & .048 & .299 & ns \\
\hline Tenaga Kerja & $\mathrm{X} 7$ & -.395 & .011 & $*$ & $\mathrm{X} 6$ & .315 & .036 & $*$ \\
\hline Usia petani & $\mathrm{X} 8$ & .923 & .000 & $* *$ & $\mathrm{X} 7$ & .429 & .080 & ns \\
\hline $\begin{array}{l}\text { Pengalaman petani } \\
\text { bertani jagung }\end{array}$ & X9 & -.192 & .027 & $*$ & $\mathrm{X} 8$ & -.101 & .202 & ns \\
\hline $\begin{array}{l}\text { Keikutsertaan petani } \\
\text { dalam penyuluhan } \\
\text { jagung }\end{array}$ & $\mathrm{X} 10$ & .026 & .834 & ns & X9 & .015 & .770 & ns \\
\hline Varietas hibrida & D1 & .173 & .001 & $* *$ & & & & \\
\hline Nilai F & & 51.223 & .000 & $* *$ & & 53.601 & .000 & $* *$ \\
\hline $\begin{array}{l}\text { Adjusted R Aquare } \\
\left(\mathrm{R}^{2}\right)\end{array}$ & & .848 & & & & .865 & & \\
\hline
\end{tabular}

Sumber: Data Primer Penelitian 2017 (Diolah)

Keterangan: ${ }^{* *}$ sangat nyata $(\alpha=1 \%),{ }^{*}$ nyata $(\alpha=5 \%),{ }^{\text {ns }}$ tidak berpengaruh nyata 
berpengaruh nyata pada produksi jagung. Hasil ini sesuai dengan hasil penelitian Fadwiwati dan Tahir (2013), dan Nursan (2015) yang menyatakan bahwa tenaga kerja berpengaruh nyata terhadap produksi jagung. Usia mempunyai pengaruh nyata pada usahatani jagung hibrida. Rata-rata usia petani responden jagung hibrida berada pada usia produktif yakni berusia 53 tahun. Menurut Badan Pusat Statistik (2016) usia produktif berada dalam rentang usia $15-64$ tahun. Usia produktif merupakan usia ideal untuk bekerja atau melakukan kegiatankegiatan didalam usahatani dan diluar usahatani dengan baik, serta mempunyai kemampuan untuk meningkatkan produktivitas kerja. Petani berada pada usia produktif cukup potensial untuk melakukan usahataninya, karena 100 persen responden petani jagung hibrida dan lokal pada usahataninya mempunyai dua peran yaitu sebagai pengelola dan tenaga kerja.

Pengalaman petani jagung hibrida dan jagung lokal mempunyai nilai koefisien regresi dari keduanya negatif. Rata-rata pengalaman bertani responden berkisar 45 47 kali bertanam jagung. Hal ini dikarenakan, dicapainya selama ini dengan kebiasaan bertani secara konvensional. Hasil penelitian dari Widiyanti (2016) bahwa pengalaman berusahatani jagung berkorelasi negatif terhadap motivasi petani dalam menerapkan inovasi yang artinya meningkatnya pengalaman bertani jagung ada petani akan menurunkan motivasi petani untuk menerapkan inovasi. Hasil penelitian Syaifullah et al. (2014), menunjukkan bahwa tinggi rendahnya pengalaman seorang petani jagung tidak dapat meningkatkan hasil produksi jagung karena petani yang berpengalaman dominan mengamplikasikan pengalamannya sendiri untuk melakukan usahatani dengan mengabaikan adanya inovasi teknologi baru yang sudah teruji kelayakannnya di dalam meningkatkan hasil produksinya.

Perbedaan varietas jagung hibrida berpengaruh terhadap produksi jagung hibrida. Varietas jagung hibrida di wilayah penelitian pada musin tanam I (September 2016 - Januari 2017) pada umumnya petani menanam jagung varietas Bisi 18 dan Pioneer 21. Nilai koefisien regresi varietas Bisi 18 positif sebesar 0,173. Sesuai dengan

Tabel 2. Hasil Perhitungan Efisiensi Ekonomi (NPMxi/Pxi) Penggunaan Faktor-faktor Produksi Usahatani Jagung Hibrida dan Jagung Lokal

\begin{tabular}{lcccc}
\hline \multirow{2}{*}{ Faktor Produksi } & \multicolumn{2}{c}{ Jagung Hibrida } & \multicolumn{2}{c}{ Jagung Lokal } \\
\cline { 2 - 5 } & NPMxi/Pxi & Keterangan & NPMxi/Pxi & Keterangan \\
\hline Benih & 16,62 & BE & 16,51 & BE \\
Pupuk kandang & 8,45 & BE & 7,08 & BE \\
Pupuk urea & $-2,50$ & TE & $-2,12$ & TE \\
Pupuk NPK & 7,10 & BE & 5,54 & BE \\
Pupuk SP36 & 7,79 & BE & & - \\
Pestisida & $-0,29$ & TE & 0,95 & TE \\
Tenaga kerja & $-1,28$ & TE & 0,62 & TE
\end{tabular}

Keterangan: $\mathrm{BE}=$ belum efisien, $\mathrm{TE}=$ tidak efisien

PMxi $=($ koefisien regresi $\mathrm{x}$ output rata-rata $) /$ input rata-rata

NPMxi $=$ PMxi $x$ Py

petani responden cenderung sudah merasa nyaman dengan hasil produksi yang sudah informasi dari Direktorat Jenderal Tanaman Pangan (2016), bahwa keunggulan dari 
varietas Bisi 18 yaitu tahan terhadap bulai dan karat daun, sedangkan varietas pioneer 21 hanya tahan terhadap penyakit karat daun dan kekeringan.

\section{Analisis Efisiensi Ekonomi Usahatani Jagung}

Tabel 2, menunjukkan bahwa secara ekonomi penggunaan variabel benih, pupuk kandang, pupuk NPK dan pupuk SP36 pada usahatani jagung hibrida belum efisien, dan penggunaan variabel pupuk Urea, pestisida dan tenaga kerja sudah tidak efisien. Penggunaan variabel benih, pupuk kandang, dan pupuk NPK belum efisien, penggunaan variabel pupuk urea, pestisida dan tenaga kerja pada usahatani jagung lokal tidak efisien. Nilai NPMxi/Pxi variabel benih pada usahatani jagung hibrida dan lokal lebih besar dari satu $(>1)$, yang masing-masing sebesar 16,62 dan 16,51, yang berarti secara ekonomis alokasi penggunaan faktor poduksi benih per usahatani jagung hibrida dan lokal belum efisien. Penggunaan benih pada usahatani jagung hibrida dan lokal perlu ditambahkan untuk meningkatkan produksi dan pendapatan petani. Hal ini sejalan dengan penelitian Antara (2010) yang menemukan bahwa setiap penambahan penggunaan jumlah benih jagung hibrida dan non hibrida signifikan terhadap peningkatan produksi jagung hibrida dan jagung non hibrida. Ratarata penggunaan benih jagung hibrida sebesar $15,14 \mathrm{~kg} / \mathrm{ha}$ dan jagung lokal $16,83 \mathrm{~kg} / \mathrm{ha}$ jarak tanam untuk usahatani jagung hibrida dengan 1-2 benih per lubang dan untuk usahatani jagung lokal dengan 2-3 benih per lubang. Kebutuhan benih untuk satu hektar lahan kering yaitu sebesar 15 - $20 \mathrm{~kg}$ dengan jarak tanam jarak antar baris $\pm 70 \mathrm{~cm}$ dan jarak antar tanaman dalam baris $\pm 20 \mathrm{~cm}$, dan 1 biji per lubang (Badan Penelitian dan Pengembangan Pertanian, 2008). Sejalan dengan usaha menambah jumlah benih, petani juga harus memperhatikan jarak tanam dan jumlah benih yang di tanam setiap lubangnya. Hasil penelitian Erawati dan Hipi (2016), menyatakan bahwa jarak tanam berpengaruh nyata terhadap peningkatan hasil biji jagung.
Area yang lebih longgar akan lebih memudahkan tanaman untuk fotosintesis dan menghasilkan asimilat untuk memproduksi biji.

Nilai NPMxi/Pxi pupuk kandang pada usahatani jagung hibrida dan lokal lebih besar dari satu $(>1)$, yang masing-masing sebesar 8,45 dan 7,08 , yang berarti secara ekonomis alokasi dari penggunaan per usahatani jagung hibrida dan jagung lokal untuk faktor produksi pupuk kandang masih relatif belum efisien. Dosis pemakaian pupuk kandang oleh petani, rata-rata belum maksimal sesuai anjuran sebesar 1500-3000 kg/ha (Badan Penelitian dan Pengembangan Pertanian, 2008), sehingga diperlukan penambahan alokasi pupuk kandang guna meningkatkan produksi dan pendapatan petani. Antara (2010) menyatakan bahwa adanya kenaikan penggunaan pupuk kandang pada usahatani agung hibrida dan non hibrida akan meningkatkan produksi jagung hibrida dan jagung non hibrida.

Nilai NPMxi/Pxi pupuk urea pada usahatani jagung hibrida dan lokal kurang dari satu $(<1)$, yang masing-masing sebesar $-2,50$ dan $-2,12$, yang berarti secara ekonomis alokasi dari penggunaan per usahatani jagung hibrida untuk faktor produksi pupuk urea telah melebihi optimal sehingga relatif tidak efisien. Secara ekonomi, penggunaan pupuk urea yang berlebihan mengakibatkan biaya untuk pembelian pupuk tidak sebanding dengan produksi yang dihasilkan, sehingga untuk memperoleh tingkat keuntungan maksimum oleh petani jagung maka penggunaan pupuk urea pada usahatani jagung hibrida dan jagung lokal perlu dikurangi. Selain itu, pupuk urea mempunyai sifat asam dan hidroskopis. Penggunaan pupuk urea yang tidak tepat waktu dan tepat dosis akan dapat menurunkan produksi. Penggunaan yang tidak tepat waktu akan menyebabkan pupuk urea menghilang karena kelebihan air atau karena kemarau, serta penggunaan yang berlebihan mengakibatkan turunnya $\mathrm{pH}$ tanah dan tanah menjadi padat (tidak subur) sehingga menghambat perkembangan akar dan pertumbuhan 
tanaman. Jumlah pupuk urea yang dianjurkan sebesar 250 - $300 \mathrm{~kg} / \mathrm{ha}$ lahan jagung (PT Petrokimia Gresik, 2017). Hal ini juga sesuai dengan hasil penelitian dari Akil (2009) yaitu takaran pupuk urea $300 \mathrm{~kg} / \mathrm{ha}$ memberikan hasil yang terbaik pada lahan sawah tadah hujan. Selain itu tidak efisiennya penggunaan pupuk urea akibat mahalnya harga pupuk urea yaitu rata-rata sekitar Rp 2.068/kg - Rp $2.106 / \mathrm{kg}$ atau lebih tinggi dari harga eceran tertinggi (HET) pupuk urea $\mathrm{Rp} 1.800 / \mathrm{kg}$ (Peraturan Menteri Pertanian RI, 2016).

Nilai NPMxi/Pi faktor produksi pupuk NPK pada usahatani jagung hibrida dan lokal lebih besar dari satu $(>1)$, yang masingmasing sebesar 7,10 dan 5,54, yang berarti secara ekonomis alokasi dari penggunaan per usahatani jagung hibrida untuk faktor produksi pupuk NPK masih relatif belum efisien. Rata-rata penggunaan pupuk NPK oleh petani jagung hibrida dan lokal masih dibawah anjuran, sehingga penambahan alokasi pupuk NPK perlu dilakukan sampai batas yang dianjurkan untuk meningkatkan produksi dan pendapatan petani. Dosis penggunaan pupuk NPK yang direkomendasikan oleh PPL Kecamatan Kemusu dan Formulator dari PT Petrokimia Gresik yaitu penggunaan pupuk NPK sebesar $300 \mathrm{~kg} / \mathrm{ha}$ lahan jagung. Penambahan pupuk NPK, sesuai dengan hasil analisis pengaruh bahwa adanya peningkatan penggunaan pupuk NPK berpengaruh nyata terhadap peningkatan produksi jagung hibrida dan lokal. Hasil ini sejalan dengan hasil penelitian Fadwiwati dan Tahir (2013) yang menyatakan bahwa adanya penambahan pupuk NPK phonska secara nyata dapat menaikan produksi jagung.

Nilai NPMxi/Pi faktor produksi pupuk SP 36 pada usahatani jagung hibrida sebesar 7,79 atau lebih besar dari satu $(>1)$, yang berarti secara ekonomis alokasi dari penggunaan untuk pupuk SP 36 masih relatif belum efisien. Penambahan pupuk SP 36 perlu ditambahkan guna memperoleh tingkat pendapatan maksimum oleh petani jagung hibrida. Penambahan pupuk SP 36 pada usahatani jagung Hibrida dapat dilakukan sampai batas maksimal dosis yang dianjurkan sebesar Rp 200 kg/ha (Badan Penelitian dan Pengembangan Pertanian, 2008). Berdasarkan laporan hasil analisa tanah di Kecamatan Kemusu oleh PT Petrokimia Gresik Tahun 2017 bahwa tanah di daerah Kemusu memiliki kandungan fosfat (P) yang rendah. Penggunaan pupuk SP 36 untuk meningkatkan unsur $\mathrm{P}$ tanah lebih ekonomis, karena rata-rata selisih harga pupuk SP 36 dengan pupuk NPK Rp 300/kg - Rp 400/kg atau harga pupuk SP 36 lebih murah dari pupuk NPK, serta kandungan unsur P pada pupuk SP 36 lebih tinggi dari pupuk NPK.

Nilai NPMxi/Pxi faktor produksi pestisida pada usahatani jagung hibrida yang masing-masing sebesar -0,29 dan 0,95, yang berarti secara ekonomis alokasi dari penggunaan per usahatani jagung hibrida untuk faktor produksi pestisida sebesar 2,33 liter telah melebihi optimal sehingga relatif tidak efisien. Dalam rangka untuk memperoleh tingkat pendapatan maksimum oleh petani jagung hibrida maka penggunaan pupuk pestisida pada usahatani jagung hibrida perlu dikurangi, sedangkan secara ekonomis alokasi dari penggunaan per usahatani jagung hibrida untuk faktor produksi pestisida telah melebihi optimal yaitu masing-masing 8,72 lt/ha dan 11,21 1tr/ha sehingga tidak efisien. Hal ini disebabkan petani dalam penakaran pemakaian pestisida pada umumnya mengirangira dengan menggunakan tutup botol pestisida, serta pada umumnya petani mencampurkan pestisida berdasarkan pengalaman teman dan tidak memperhatikan ukuran dosis yang dianjurkan, bahkan tidak membaca label kemasan. Menurut Sembodo (2010) bahwa dosis herbisida yang tepat akan dapat mengendalikan gulma sasaran, tetapi jika dosisnya terlalu tinggi dapat meracuni dan merusak tanaman budidaya, dan Menurut Bilman (2011) bahwa Gulma yang dibiarkan tanpa pengendalian pada jagung dapat menurunkan hasil 20 - 80 persen, akan tetapi penggunaan pestisida yang berlebihan dapat menyebabkan kematian tidak saja pada gulma tapi juga tanaman jagung yang dibudidayakan. Rekomendasi dari Badan 
Penelitian dan Pengembangan Pertanian (2008), bahwa penggunaan benih dalam satu hektar lahan jagung sekitar 1 - 2 ltr/ha. Secara ekonomis, pengurangan pertisida dapat mengurangi biaya produksi sehingga pendapatan petani tinggi. Harga rata-rata pestisida jenis herbisida yang digunakan petani berkisar Rp 69.753/ltr - Rp 70.528/ltr. Rasio antara NPMxi/Pxi tenaga kerja pada usahatani jagung hibrida dan lokal lebih kecil dari 1 yaitu masing-masing sebesar -1,28 dan 0,62 , yang berarti secara ekonomis penggunaan faktor produksi tenaga kerja pada usahatani jagung hibrida dan lokal tidak efisien (terlalu banyak tenaga kerja yang digunakan). Penggunaan tenaga kerja yang berlebihaan berpengaruh pada biaya usahatani yang dikeluarkan. Hasil analisis biaya usahatani menunjukkan bahwa biaya tenaga kerja yang keluarkan oleh petani jagung hibrida dan jagung lokal cukup besar dari total biaya prosuksi, masing-masing sebesar 59 persen dan 67 persen dari total biaya produksi, yang artinya bahwa agar petani mendapatkan pendapatan yang maksimal dapat dilakukan dengan pengurangan jumlah tenaga kerja. Menurut Fauziyah (2010) menyatakan bahwa kelebihan jumlah tenaga kerja tidak berdampak pada hasil produksi namun berdampak pada keuntungan yang diterima petani, semakin tinggi jumlah tenaga kerja maka semakin tinggi biaya usahatani yang akan menyebabkan pendapatan petani berkurang.

\section{Analisis Pendapatan Usahatani}

Berdasarkan hasil analisis struktur pembiayaan dan pendapatan usahatani jagung hibrida dan jagung lokal dalam luasan lahan yang sama yaitu satu hektar lahan, maka tampak bahwa, pendapatan usahatani petani jagung hibrida di daerah penelitian relatif masih lebih tinggi dengan $\mathrm{R} / \mathrm{C}$ ratio sebesar 2,13, jika dibandingkan dengan usahatani jagung lokal dengan $\mathrm{R} / \mathrm{C}$ ratio sebesar 1,54 (Tabel 3). Produksi jagung pada usahatani jagung hibrida lebih tinggi 82,45 persen dari produksi jagung lokal atau mencapai sebesar $4.857 \mathrm{~kg}$ jagung pipilan kering, meskipun harga jual jagung hibrida lebih rendah $(25,09$ persen) dari harga jual jagung lokal. Rata-rata penerimaan petani responden jagung hibrida sebesar Rp 17.636.911,- atau lebih tinggi 36,70 persen) jika dibandingkan dengan penerimaan usahatani jagung lokal Rp 12.901.827,-. Selain itu, biaya yang dikeluarkan dalam berusahatani jagung hibrida lebih kecil (1,00 persen) dari biaya yang dikeluarkan petani jagung lokal.

Analisis perbandingan pendapatan petani jagung hibrida dengan petani jagung lokal digunakan uji beda (compare means) yaitu independent sample t-test. Independent sample t-test menurut Wijaya (2013) merupakan analisis yang digunakan untuk menguji ada tidaknya perbedaan rata-rata antar dua kelompok yang saling independen secara signifikan (tidak ada hubungan antara dua sampel), serta jumlah responden (n) antar dua kelompok boleh berbeda. Hasil uji beda independent sample t-test antara pendapatan ( $\mathrm{R} / \mathrm{C}$ ratio) usahatani jagung hibrida dan jagung lokal pada luas lahan satu hektar, menunjukkan bahwa ada perbedaan yang nyata (sig.0,000). Pernyataan ini sesuai dengan hasil penelitian dari Fadwiwati dan Tahir (2013) di Provinsi Gorontalo bahwa usahatani jagung dengan menggunakan benih varietas unggul baru (VUB) lebih menguntungkan jika dibandingkan menggunakan benih jagung varietas unggul lama (VUL), dengan $\mathrm{R} / \mathrm{C}$ ratio masingmasing sebesar 2,68 dan 1,98. Antara (2010), juga menyatakan bahwa usahatani jagung di Kecamatan Palolo Kabupaten Sigi dengan menggunakan benih jagung hibrida lebih menguntungkan jika dibandingkan dengan benih jagung non hibrida dengan $\mathrm{R} / \mathrm{C}$ ratio masing-masing sebesar sebesar 2,22 dan 1,95. 
Tabel 3. Analisis Rata-rata Pendapatan Usahatani Jagung Hibrida dan Lokal Kecamatan Kemusu Musim Tanam Periode September 2016 s.d. Januari 2017 (Per hektar)

\begin{tabular}{|c|c|c|c|c|c|}
\hline Keterangan & Satuan & Jagung Hibrida & $\begin{array}{c}\text { Porporsi } \\
\text { terhadap } \\
\text { Biaya }\end{array}$ & Jagung Lokal & $\begin{array}{c}\text { Porporsi } \\
\text { terhadap } \\
\text { Biaya }\end{array}$ \\
\hline & & & ----\%/0---- & & ----\%\%---- \\
\hline Penerimaan & $\mathrm{Rp} / \mathrm{ha}$ & 17.636 .911 & & 12.901 .827 & \\
\hline Produksi Jagung & $\mathrm{kg} / \mathrm{ha}$ & 4.857 & & 2.662 & \\
\hline Harga jual & $\mathrm{Rp} / \mathrm{kg}$ & 3.631 & & 4.847 & \\
\hline Biaya Variabel & $\mathrm{Rp} / \mathrm{ha}$ & 8.102.787 & 97,97 & 8.186 .103 & $\mathbf{9 7 , 5 8}$ \\
\hline Benih & $\mathrm{Rp} / \mathrm{ha}$ & 981.328 & 11,87 & 402.228 & 4,79 \\
\hline Pupuk kandang & $\mathrm{Rp} / \mathrm{ha}$ & 222.334 & 2,69 & 246.287 & 2,94 \\
\hline Pupuk Urea & $\mathrm{Rp} / \mathrm{ha}$ & 647.080 & 7,82 & 606.068 & 7,22 \\
\hline Pupuk NPK & $\mathrm{Rp} / \mathrm{ha}$ & 691.336 & 8,36 & 665.291 & 7,93 \\
\hline Pupuk SP 36 & $\mathrm{Rp} / \mathrm{ha}$ & 171.245 & 2,07 & - & \\
\hline Pestisida & $\mathrm{Rp} / \mathrm{ha}$ & 518.615 & 6,27 & 635.015 & 7,57 \\
\hline Tenaga Kerja & $\mathrm{Rp} / \mathrm{ha}$ & 4.870 .849 & 58,89 & 5.631 .214 & 67,12 \\
\hline Biaya Tetap & $\mathrm{Rp} / \mathrm{ha}$ & 167.622 & $\mathbf{2 , 0 3}$ & 203.253 & 2,42 \\
\hline Sewa lahan & $\mathrm{Rp} / \mathrm{ha}$ & 135.445 & 1,64 & 176.533 & 2,10 \\
\hline Penyusutan alat & $\mathrm{Rp} / \mathrm{ha}$ & 32.177 & 0,39 & 26.720 & 0,32 \\
\hline Total Biaya & $\mathrm{Rp} / \mathrm{ha}$ & 8.270 .410 & & 8.389.356 & \\
\hline Pendapatan & $\mathrm{Rp} / \mathrm{ha}$ & 9.366 .501 & & 4.512 .470 & \\
\hline $\mathrm{R} / \mathrm{C}$ ratio & & 2,13 & & 1,54 & \\
\hline
\end{tabular}

Sumber: Data Primer (diolah), 2017

\section{SIMPULAN DAN SARAN}

Berdasarkan hasil penelitian yang dilaksanakan di Kecamatan Kemusu Kabupaten Boyolali terhadap usahatani jagung pada musim tanam periode September 2016 sampai dengan Januari 2017, dapat disimpulkan bahwa:

1. Produksi jagung hibrida di Kecamatan Kemusu Kabupaten Boyolali dipengaruhi oleh variabel jumlah benih, pupuk NPK, tenaga kerja, usia petani, pengalaman petani bertani jagung, dan dummy vaietas jagung berpengaruh nyata. Produksi jagung lokal secara nyata dipengaruhi oleh variabel jumlah benih, pupuk kandang, pupuk NPK, dan tenaga kerja.

2. Secara ekonomi penggunaan variabel benih, pupuk kandang, pupuk NPK dan pupuk SP36 pada usahatani jagung hibrida relatif belum efisien, dan menggunaan variabel pupuk Urea, pestisida dan tenaga kerja sudah tidak efisien. Penggunaan variabel benih, pupuk kandang, dan pupuk NPK belum efisien, penggunaan variabel pupuk urea, pestisida dan tenaga kerja pada usahatani jagung lokal sudah tidak efisien.

3. Usahatani jagung di Kecamatan Kemusu Kabupaten Boyolali pada periode tanam September sampai dengan Desember 2017 menguntungkan dan masih layak diusahakan $(\mathrm{R} / \mathrm{C}>1)$. Pendapatan usahatani jagung hibrida lebih menguntungkan dibandingkan usahatani jagung lokal. Besarnya $\mathrm{R} / \mathrm{C}$ ratio usahatani jagung hibrida 2,13 dan jagung lokal 1,54.

\section{UCAPAN TERIMAKASIH}

Ucapan terima kasih saya sampaikan kepada pihak Badan Penyuluhan \& Pengembangan Sumberdaya ManusiaKementerian Pertanian RI sebagai penyandang dana penelitian ini.

\section{DAFTAR PUSTAKA}


Akil, M. 2009. Aplikasi pupuk urea pada tanaman jagung. Balai Penelitian Tanaman Serealia. Proshiding. Seminar Nasional Serealia Tahun 2009. p. 169176.

Antara, M. 2010. Analisis produksi dan komparatif antara usahatani jagung hibrida dengan nonhibrida di Kecamatan Palolo Kabupaten Sigi. Jurnal Agroland 17(1): 56-62.

Ayub, S. dan Pranata. 2010. Meningkatkan Hasil Panen dengan Pupuk Organik. Agromedia Pustaka. Jakarta

Badan Ketahanan Pangan. 2016. Neraca Bahan Makanan Tahun 2006-2015. Kementerian Pertanian. Jakarta.

Badan Penelitian dan Pengembangan Pertanian. 2008. Panduan Umum Pengelolaan Tanaman Terpadu Jagung. Departemen Pertanian. Jakarta.

Badan Pusat Statistik Kabupaten Boyolali. 2016. Boyolali Dalam Angka: Luas Panen, Produktivitas, dan Produksi Jagung di Kabupaten Boyolali Tahun 2006-2015. Boyolali.

Badan Pusat Statistik. 2016. Data Luas Panen, Produktivitas, dan Produksi Jagung Tahun 2011-2015. Jakarta.

Bilman. 2011. Analisis pertumbuhan tanaman jagung (Zea Mays L.), pergeseran komposisi gulma pada beberapa jarak tanam dan pengolahan tanah. Jurnal Ilmu-Ilmu Pertanian Indonesia. 3 (1): 25-31.

Direktorat Jenderal Tanaman Pangan. 2016. Petunjuk Teknis Gerakan Pengembangan Jagung Hibrida 2016. Kementerian Pertanian. Jakarta.

Erawati, B.T.R dan A. Hipi. 2016. Pengaruh jarak tanam terhadap pertumbuhan dan hasil beberapa varietas jagung hibrida di kawasan pengembangan jagung Kabupaten Sumbawa. Prosiding. Seminar Nasional Inovasi Teknologi Pertanian. p. 608-616.

Fadwiwati, A.Y., dan Tahir. 2013. Analisis faktor-faktor produksi yang mempengaruhi produksi dan pendapatan usahatani jagung di Provinsi Gorontalo. Jurnal Pengkajian dan Pengembangan Teknologi Pertanian. 16(2): 92-101.

Fauziyah, E. 2010. Analisis efisiensi teknis usahatani tembakau (suatu kajian dengan menggunakan fungsi produksi frontier stokastik). Journal Embryo. 7(1): $1-7$.

Ghozali, I. 2011. Ekonometrika: Teori, Konsep, dan Aplikasi dengan SPSS 17. Badan Penerbit Universitas Diponegoro. Semarang.

Isaac, O. 2011. Technical efficiency of maize production in Oyo State. Journal Of Economics And International Finance. 3(4): 211-216.

Kasno, A., dan T. Rostaman. 2013. Serapan hara dan peningkatan produktivitas jagung dengan aplikasi pupuk npk majemuk. Balai Penelitian Tanah Cimanggu Bogor. Jurnal Penelitian Pertanian Tanaman Pangan. 32(3): 179186.

Meade, G., S.T.J. Lalor, and T.Mc. Cabe. 2011. An Evaluation of the combined usage of separated liquid pig manure and inorganic fertilizer in nutrient programmes for winter wheat production. European Journal of Agronomy 34(2): 62-70.

Nursan, M. 2015. Efisiensi Dan Daya Saing Usahatani Jagung Pada Lahan Kering Dan Sawah Di Kabupaten Sumbawa. Tesis. Pascasarjana Institut Pertanian Bogor. Bogor.

Peraturan Menteri Pertanian RI. 2016. Peraturan Menteri Pertanian RI Nomor: 69/Permentan/SR.310/12/2016 Tentang Alokasi dan Harga Eceran Tertinggi Pupuk Bersubsidi Untuk Sektor Pertanian tahun Anggaran 2017. Kementerian Pertanian. Jakarta.

PT Petrokimia Gresik. 2017. Budidaya Tanaman Menggunakan Phonska Petroganik. Pupuk Indonesia Holding Company. Palembang.

Pratikta, D, S. Hartatik, dan K.A. Wijaya. 2013. Pengaruh penambahan pupuk 
NPK terhadap beberapa aksesi tanaman jagung (Zea mays L.). Journal Berkala Ilmiah Pertanian. 1(2): 19-21.

Pusat Data dan Informasi Kementerian Pertanian. 2016. Data Impor Tahun 2006-2015. Kementerian Pertanian. Jakarta.

Saptana. 2011. Efisiensi Produksi Dan Perilaku Petani Terhadap Risiko Produktivitas Cabai Merah Di Provinsi Jawa Tengah. Disertasi. Pascasarjana Institut Pertanian Bogor. Bogor.

Sembodo, D. R. J. 2010. Gulma dan Pengelolaannya. Graha Ilmu. Yogyakarta.

Shinta, A. 2011. Ilmu Usahatani. Universitas Brawijaya Press. Malang.

Soekartawi. 2002. Teori Ekonomi Produksi, Dengan Pokok Bahasan Analisis Fungsi Cobb-Douglas. PT Raja Grafindo Persada. Jakarta.

Soekartawi. 2016. Analisis Usahatani. UI Press. Jakarta.

Suratiyah, K. 2015. Ilmu Usahatani. Penebar Swadaya. Jakarta.

Syaifullah, M.I, A.F, Sunartomo, dan Sudarko. 2014. Pengaruh faktor-faktor eksternal dan internal terhadap partisipasi dan hasil produksi jagung di Desa Tutul Kecamatan Baung Kabupaten Jember (Studi Kasus Penyuluhan PT. Syngenta Indonesia). Journal Berkala Ilmiah Pertanian (BIP). p. 1-13.

Togatorop, R.B. 2011. Analisis efisiensi produksi dan pendapatan pada usahatani jagung di Kecamatan Wirosari, Kabupaten Grobogan. Jurnal. http://eprints.Universitas

Diponegoro.ac.id/26497/1/buat_jurnal.p df. Diakses tanggal 11 Maret 2017.

Widiyanti. 2016. Kinerja Usahatani dan Motivasi Petani dalam Penerapan
Inovasi Benih Jagung Hibrida pada Lahan Kering di Kabupaten Lombok Timur. Tesis. Pascasarjana Institut Pertanian Bogor. Bogor.

Wijaya, T. 2013. Metodologi Penelitian Ekonomi dan Bisnis, Teori dan Praktik. Graha Ilmu. Yogyakarta. 